\title{
UJI KONSENTRASI EKSTRAK SERAI WANGI TERHADAP MORTALITAS ULAT GRAYAK JAGUNG
}

\author{
Concentration Test of Citronella Oil Extract in Controlling Fall Armyworms
}

\author{
Rusli Rustam, Anggita CinthiaTarigan \\ Jurusan Agroteknologi, Fakultas Pertanian, Universitas Riau \\ Email:Anggita.cinthia6039@ student.unri.ac.id/082283470299
}

[Diterima: Agustus 2021; Disetujui: November 2021 ]

\begin{abstract}
Fall armyworm (Spodoptera frugiperda J. E. Smith) is a major pest of corn. The usual control is the use of synthetic insecticides, but the continuous or unwise use of synthetic insecticides will harm humans and the environment. Therefore an alternative insecticide, called botanical pesticide that is safe and environmentally friendly such as extract citronella extract (Cymbopogon nardus L.) is needed. The purpose of this study was to obtain an effective extract concentration of Cymbopogon nardus L.to control $S$. frugiperda. The research was conducted at the Plant Pest Laboratory of the Faculty of Agriculture, Riau University, Pekanbaru. The study was done from August to September 2020. This research used a completely randomized design (CRD), consisting of 6 treatments and 4 replications with the concentration was 2 ml.1-1 water, 4 ml.1-1 water, 6 ml.l-1 water, 8 ml.l-1 water, $10 \mathrm{ml} .1-1$ water and without extract as a control. The result of the research showed that the concentration of 6 ml.1-1 water was able to control the $S$. frugiperda and could cause total mortality of $80 \%$ with an initial time of death of 6.75 hours after application, 50 lethal times of 40.50 hours.
\end{abstract}

Keywords: Cymbopogon nardus L, Spodoptera frugiperda, Corn, Botanical pesticide

\begin{abstract}
ABSTRAK
Ulat grayak jagung (Spodoptera frugiperda J.E.Smith) adalah hama utama pada tanaman jagung. Pengendalian yang dilakukan pada umumnya ialah dengan menggunakan insektisida sintetik, akan tetapi penggunaan insektisida sintetik secara terus-menerus akan menimbulkan dampak negative bagi manusia dan lingkungan. Salah satu alternative pengendalian yang dapat digunakan ialah pestisida botani yang aman serta ramah lingkungan seperti minyak serai wangi (Cymbopogon nardus L.). Tujuan penelitan ialah untuk mendapatkan ekstrak minyak serai yang efektif untuk mengendalikan spodoptera frugiperda. Penelitian dilaksanakan di Laboratorium Hama Tumbuhan Fakultas Pertanian Universitas Riau, Pekanbaru. Penelitian berlangsung dari bulan Agustus sampai dengan bulan September 2020. Penelitian dilakukan secara eksperimen dengan rancangan acak lengkap (RAL), yang terdiri dari enam perlakuan dan empat ulangan sehingga diperoleh 24 unit percobaan. Perlakuan yang diberikan adalah pemberian konsentrasi minyak serai dengan konsentrasi 2 ml..$^{-1}$ air, 4 ml..$^{-1}$ air, $6 \mathrm{ml} .1^{-1}$ air, $8 \mathrm{ml} . \mathrm{l}^{-1}$ air dan $10 \mathrm{ml.1}{ }^{-1}$ air.dan $0 \mathrm{ml} . \mathrm{l}^{-1}$ air sebagai control. Hasil penelitian menunjukkan bahwa aplikasi minyak serai memberikan pengaruh yang nyata dalam mematikan larva Spodoptera frugiperda J.E Smith. Konsentrasi $6 \mathrm{ml} . \mathrm{l}^{-1}$ air merupakan konsentrasi yang efektif dalam mengendalikan larva dengan mortalitas total sebesar 80\%, waktu awal kematian 6,75 jam setelah aplikasi dan $\mathrm{LT}_{50}$ sebesar 40,50 jam setelah aplikasi.
\end{abstract}

Kata kunci: Cymbopogon nardus L, Spodoptera frugiperda, Jagung, Pestisida botani .

\section{PENDAHULUAN}

Jagung merupakan kelompok dari tanaman serealia yang memiliki peran penting dalam memenuhi kebutuhan karbohidrat masyarakat setelah padi. Jagung juga berperan penting dalam upaya ketahanan pangan nasional. Kebutuhan pasar akan jagung di ProvinsiRiau meningkat setiap tahunnya seiring dengan peningkatan jumlah penduduk dan industri yang membutuhkan jagung sebagai bahan baku. 
KementerianPertanian (2020) menyatakan produksi jagung di Riau pada tahun 2017 yaitu sebesar 30.765 ton, pada tahun 2018 mencapai 25.723 ton dan pada tahun 2019 mencapai 70.599 ton. Produksi tanaman jagung tidak terlepas dari beberapa kendala sehingga hasil produksi jagung belum optimal.Serangan hama pada tanaman jagung menjadi salah satu kendala dalam budidaya jagung yang dapat menyebabkan kerusakan pada tanaman dan berkurangnya produksi tanaman jagung. Hama yang menyerang jagung diantaranya adalah ulat grayak jagung (Spodoptera frugiperda J.E. Smith).

Spodoptera frugiperda J.E. Smith merupakan serangga invasif yang telah menjadi hama pada tanaman jagung (Zea mays) di Indonesia. Serangga ini berasal dari Amerika dan telah menyebar di berbagai negara. Pada awal tahun 2019, hama ini ditemukan pada tanaman jagung di daerah Sumatera (Kementerian Pertanian, 2019). Hama ini bersifat polifag dan mudah menyebar. Serangan S. frugiperda J.E. Smith ditemukan menyerang tanaman jagung, padi, gandum dan tebu (CABI, 2019). Kerusakan pada tanaman biasanya ditandai dengan bekas gerekan larva, yaitu terdapat serbuk kasar menyerupai serbuk gergaji pada permukaan atas daun, atau di sekitar pucuk tanaman jagung. Jika pucuk tanaman diserang akan menyebabkan matinya tanaman (Direktorat Jenderal Perkebunan, 2019).Maharani et al., (2019) menyatakan serangan S. frugiperda dapat menyebabkan kehilangan hasil pada tanaman jagung sebesar 4-8 juta ton pertahun. Infestasi ulat grayak pada tanaman jagung saat daun muda yang masih menggulung menyebabkan kehilangan hasil $15-73 \%$ jika populasi yang terserang 55-100\%.Hama ulat grayak jagung $(S$. frugiperda) harus dikendalikan untuk menyelamatkan produksi jagung di Indonesia.

Usaha pengendalian yang dilakukan petani terhadap ulat grayak jagung (Spodotera frugiperda J.ESmith) pada umumnya menggunakan insektisida kimia sintetik. Ketergantungan petani terhadap insektisida kimia sintetik tidak terlepas dari beberapa kelebihan insektisida sintetik antara lain pengendalian kimia lebih praktis, lebih cepat dan lebih efisien dari segi ekonomi dan waktu (Dadang dan Prijono, 2008). Namun penggunaan insektisida kimia sintetik secara terus-menerus dapat menimbulkan dampak negatif diantaranya resistensi hama, resurjensi hama, peledakan hama sekunder, matinya musuh alami, menimbulkan residu, menimbulkan keracunan terhadap manusia dan pencemaran lingkungan baik tanah maupun air. Alternatif yang dapat diterapkan untuk mengurangi dampak tersebut ialah dengan menggunakan insektisida nabati yang bersifat selektif terhadap serangga dan ramah lingkungan (Untung, 1996.

Tanaman yang berpotensi sebagai insektisida nabati adalah serai wangi (Cymbopogon nardus L.). Bagian tanaman yang berpotensi mengendalikan hama adalah daun serai wangi. Daun yang diekstrak akan menghasilkan minyak atsiri dan senyawa lain seperti sitronela, sitral, geraniol, metilheptenon,eugenol-metil-ester, dipenten, eugenol, kadinen, kadinol, dan limonen (Sastrohamidjojo, 2004). Senyawa sitronela dalam daun tanaman bersifat racun kontak, racun perut dan racun pernafasan bagi serangga. Racun sitronela masuk melalui lubang- lubang alami serangga dan bekerja sebagai racun saraf dengan mekanisme mengganggu dan menghambat enzim asetilkolinesterase sehingga terjadi fosforilasi asam amino serin pada pusat asteratik enzim. Terhambatnya enzim asetilkolinesterase pada serangga akan menyebabkan penimbunan asetilkolin sehingga terjadi gangguan sistem saraf pusat, kejang, kelumpuhan pernafasan, dan kematian serangga (Mutchler, 1991).

Hasil penelitian Hasyim (2010) melaporkan bahwa minyak serai pada konsentrasi 3.0005000 ppm yang menyebabkan mortalitas sebesar $80 \%$ pada Helicoverpa armigera. Hasil penelitian Nurohmaningrum (2016) tentang minyak atsiri serai wangi terhadap larva Spodopteraexigua menunjukkan mortalitas sebesar $84 \%$ pada konsentrasi $1 \%$. Sesuai dengan pernyataan Dadang dan Prijono (2008), bahwa insektisida nabati dikatakan efektif apabila dapat menyebabkan kematian hama $\geq 80 \%$ menggunakan pelarut air dengan konsentrasi maksimal $10 \%$ dan pelarut organik pada konsentrasi tidak melebihi $1 \%$. Berdasarkan uraian di atas penulis telah melakukan penelitian berjudul "Uji Konsentrasi Ekstrak Minyak Serai Wangi 
(Cymbopogonnardus L.) terhadap Mortalitas Ulat rayak Jagung (Spodoptera frugiperdaJ.E Smith) pada Jagung (Zea mays L.) di Laboratorium".

\section{BAHAN DAN METODE}

Penelitian dilaksanakan di Laboratorium Hama Tumbuhan Fakultas Pertanian Universitas Riau, Kampus Bina Widya Km 12,5 Kelurahan Simpang Baru, Kecamatan Tampan, Pekanbaru. Penelitian dilaksanakan dari bulan Juli 2020 sampai bulan September 2020. Bahan yang digunakan dalam penelitian adalah larva Spodoptera frugiperda instar III, minyak serai wangi, aquades steril, madu, kapas, serbuk gergaji, kardus, tongkol jagung muda, kain kasa, tissue dan $5 \mathrm{ml}$ tween 20 . Alat yang digunakan dalam penelitian adalah gelas ukur $5 \mathrm{ml}$, erlenmeyer, stoples berdiameter $3,5 \mathrm{~cm}$ dan tinggi $8 \mathrm{~cm}$, stoples berdiameter $5 \mathrm{~cm}$ dan tinggi $7 \mathrm{~cm}$, stoplesukuran $15 \mathrm{~cm} \times 10 \mathrm{~cm} \times 20 \mathrm{~cm}$, karet gelang, pinset, beaker glass, kertas label, kuas, pisau, gunting, alat saring, thermohygrometer, sendok pengaduk dan kamera.Penelitian dilakukan secara eksperimen dengan menggunakan rancangan acak lengkap (RAL) dengan 6 perlakuan dan 4 kali ulangan, sehingga diperoleh 24 unit percobaan. Setiap unit percobaan terdiri dari 10 ekor larva $S$. frugiperda instar III. Perlakuan yang diberikan adalah pemberian konsentrasi minyak serai dengan konsentrasi sebagai berikut: $\mathrm{J}_{0}: 0 \mathrm{ml} . \mathrm{l}^{-1}$ air, $\mathrm{J}_{1}: 2 \mathrm{ml}^{-1}$ air, $\mathrm{J}_{2}: 4 \mathrm{ml} . \mathrm{l}^{-1}$ air, $\mathrm{J}_{3}: 6 \mathrm{ml} . \mathrm{l}^{-1}$ air, $\mathrm{J}_{4}: 8 \mathrm{ml} . \mathrm{l}^{-1}$ air dan $\mathrm{J}_{5}: 10 \mathrm{ml} . \mathrm{l}^{-1}$ air. Parameter pengamatan terdiri dari waktu awal kematian, lethal time 50, mortalitas harian, mortalitas total, suhu dan kelembapan.

\section{HASIL DAN PEMBAHASAN}

\subsection{Waktu Awal Kematian (jam)}

Hasil sidik ragam menunjukkan bahwa perlakuan konsentrasi ekstrak minyak serai wangi (Cymbopogon nardus L.) memberikan pengaruh nyata terhadap waktu awal kematian larva S. frugiperda (Lampiran 4). Hasil uji lanjut Duncan New Multiple Range Test (DNMRT) taraf 5\%parameter waktu awal kematian dapat dilihat pada Tabel 1.

Tabel 1. Rata-rata waktu awal kematian larva S. frugiperda setelah pemberian ekstrak minyak serai wangi (Cymbopogon nardus L.) (jam)

\begin{tabular}{cc}
\hline Konsentrasi ekstrak minyak serai wangi (ml.1 ${ }^{-1}$ air) & Waktu awal kematian S.frugiperda (jam) \\
\hline 0 & $120,00 \mathrm{a}$ \\
2 & $9,75 \mathrm{~b}$ \\
4 & $6,75 \mathrm{c}$ \\
6 & $6,75 \mathrm{c}$ \\
8 & $3,00 \mathrm{~d}$ \\
10 & $3,00 \mathrm{~d}$ \\
\hline
\end{tabular}

Angka-angka pada kolom setiap perlakuan yang diikuti oleh huruf kecil yang tidak sama menunjukkan berbeda nyata menurut uji DNMRT pada taraf 5\% setelah di transformasikan ke dalam $\sqrt{ } y$.

Tabel 1 menunjukkan bahwa pemberian ekstrak minyak serai wangi (Cymbopogon nardus L.) menyebabkan perbedaan terhadap waktu awal kematian larva S. frugiperda dengan kisaran waktu $3-9,75$ jam setelah aplikasi.Perlakuan konsentrasi ekstrak minyak serai $2 \mathrm{ml}^{-\mathrm{l}^{-1}}$ air menyebabkan waktu awal kematian larva $S$. frugiperda yaitu 9,75 jam setelah aplikasi dan berbeda nyata dengan konsentrasi $4 \mathrm{ml} . \mathrm{l}^{-1}$ airdan $6 \mathrm{ml}^{-\mathrm{l}^{-1}}$ air dengan waktu awal kematian 6,75 jam dan 6,75 jam. Hal ini dikarenakan semakin tinggi konsentrasi maka semakin banyak bahan aktif yang terkandung. Semakin banyak bahan aktif maka semakin tinggi daya racun yang mengakibatkan larva $S$. frugiperda cepat mengalami kematian. Aminah (1995) menyatakan bahwa tinggi rendahnya suatu konsentrasi akan mempengaruhi bahan aktif dan berpengaruh terhadap waktu awal kematian serangga uji.

Peningkatan konsentrasi ekstrak minyak serai8 ml. ${ }^{-1}$ dan $10 \mathrm{ml} . \mathrm{l}^{-1}$ air dengan awal kematian 3 jam telah mampu memperlihatkan perbedaan yang nyata dengan perlakuan yang lainnya. Hal ini diduga karena tingginya kandungan sitronela minyak serai yang masuk ke dalam tubuh larva $S$. frugiperda sehingga waktu untuk mematikan larva $S$. frugiperda 
cenderung cepat. Pendapat ini didukung oleh penelitian Sasmitaet al.,(2014) yang melaporkan bahwa serai wangi pada konsentrasi $0,5 \%$ menyebabkan waktu awal kematian Aphis gossypii3,74 jam setelah aplikasi. Mulyana (2002) menyatakan bahwa pemberian konsentrasi yang tinggi menyebabkan serangga cepat mengalami kematian, hal ini disebabkan banyaknya zat racun sitronela yang masuk ke dalam tubuh serangga melalui proses makan dan melalui lubang-lubang alami pada serangga atau melalui mulut bersama bahan makananya. Muryati et al., (2010) menambahkan bahwa minyak serai wangi mengandung senyawa sitronela yang bersifat racun perut, racun kontak dan racun syaraf. Mekanisme kerja racun sitronela adalah dengan menghambat enzim asetilkolinesterase sehingga terjadi fosforilasi asam amino atau penimbunan asetilkolin yang menyebabkan gangguan sistem saraf pusat, kejang, kelumpuhan pernafasan, dan kematian.

Gejala awal kematian larvaS. frugiperda setelah diaplikasikan insektisida minyak serai ditandai dengan pergerakan $S$. frugiperda yang melambat, nafsu makan berkurang, larva terlihat lemah dan lama-kelamaan larva mati. Juliati et al., (2016) menyatakan bahwa semakin banyak ekstrak insektisida yang menempel pada tubuh serangga atau pakannya, maka semakin banyak racun yang bereaksi dalam membunuh larva sehingga dapat menurunkan aktivitas makan dan menimbulkan kematian.

Perubahan morfologi $S$. frugiperda terlihat setelah 12 jam setelah aplikasi perlakuan. Perubahan yang terjadi adalah perubahan warna tubuh yang semula berwarna kuning kecoklatan berubah menjadi cokelat kehitaman dan lama-kelamaan menjadi hitam dan keriput. Perubahan warna yang terjadi pada tubuh S. frugiperda setelah aplikasi ekstrak minyak serai wangi diduga memperlihatkan gejala melanisasi. Pendapat ini didukung oleh Dono et al., (2006) menyatakan bahwa melanisasi melibatkan enzim polifenol oksidase yang dicirikan dengan warna cokelat atau hitam. Proses perubahan morfologi larva Spodopterafrugiperda setelah diaplikasikan minyak serai dapat dilihat pada Gambar 1.

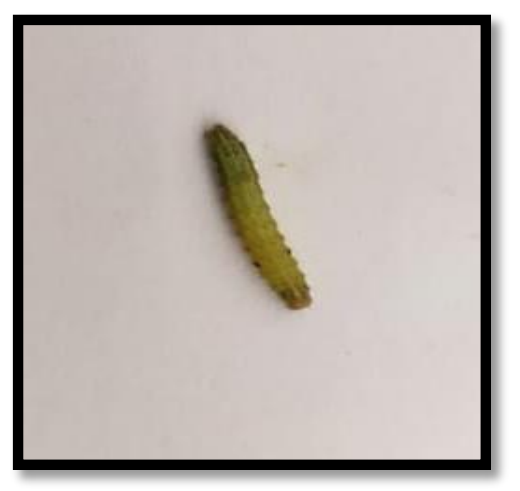

(a)

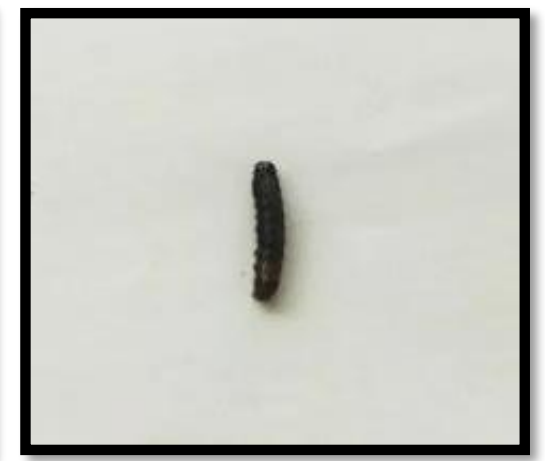

(b)

Gambar 1. Perbedaan larva S.frugiperda yang hidup dan mati 12 jam setelahaplikasi: (a)larva hidup (b)larva mati(Dokumentasi penelitian, 2020)

\subsection{Lethal Time 50}

Hasil sidik ragam menunjukkan bahwa aplikasi konsentrasi ekstrak minyak serai wangi (Cymbopogon nardus L.) memberikan pengaruh nyata terhadap lethal time $50 \quad\left(\mathrm{LT}_{50}\right)$ larva S.frugiperda (Lampiran 4). Hasil uji lanjut Duncan New Multiple Range Test (DNMRT) taraf 5\% parameter lethal time 50 (LT 50) disajikan pada Tabel 2 .

Tabel 2 menunjukkan bahwa aplikasi konsentrasi ekstrak minyak serai wangi menyebabkan perbedaan terhadap $\mathrm{LT}_{50}$ dengan kisaran 18,75-73,50 jam. Waktu yang dibutuhkan ekstrak minyak serai wangi untuk mematikan $50 \%$ larva S. frugiperda pada konsentrasi $2 \mathrm{ml}^{-1} \mathrm{l}^{-1}$ air yaitu sebesar 73,50 jam setelah aplikasi dan berbeda tidak nyata dengan konsentrasi minyak serai $4 \mathrm{ml}^{\mathrm{l}^{-1}}$ air dan $6 \mathrm{ml}^{. \mathrm{l}^{-1}}$ air dengan $\mathrm{LT}_{50} 45,00$ jam dan 40,50 jam setelah aplikasi. 
Tabel 2. Rata-rata lethal time $50\left(\mathrm{LT}_{50}\right)$ larva $S$. frugiperda setelah pemberian ekstrakminyak serai wangi (Cymbopogon nardus L.)(jam).

\begin{tabular}{cc}
\hline Konsentrasi ekstrakminyak serai wangi(ml. ${ }^{-1}$ air $)$ & Lethal time $50\left(\mathrm{LT}_{50}\right)(\mathrm{jam})$ \\
\hline 0 & $120,00 \mathrm{a}$ \\
2 & $73,50 \mathrm{~b}$ \\
4 & $45,00 \mathrm{bc}$ \\
6 & $40,50 \mathrm{bc}$ \\
10 & $28,50 \mathrm{c}$ \\
\hline
\end{tabular}

Angka-angka pada kolom setiap perlakuan yang diikuti oleh huruf kecil yang tidak sama menunjukkan berbeda nyata menurut uji DNMRT pada taraf $5 \%$ setelah di transformasikan ke dalam $\sqrt{y}$.

Semakin tinggi konsentrasi yang diberikan maka nilai $\mathrm{LT}_{50}$ akan semakin kecil. Semakin tinggi konsentrasi minyak serai yang diberikan, maka akan semakin banyak senyawa sitronela yang dihasilkan sehingga mengakibatkan kematian serangga. Pendapat ini sesuai dengan Dewi (2010) menyatakan bahwa konsentrasi ekstrak yang tinggi maka pengaruh yang ditimbulkan semakin tinggi, disamping itu daya kerja suatu senyawa sangat ditentukan oleh besarnya konsentrasi. Aplikasi konsentrasi minyak serai wangi $10 \mathrm{ml} . \mathrm{l}^{-1}$ air dan $8 \mathrm{ml} . \mathrm{l}^{-1}$ air saling berbeda tidak nyata. Hal ini sejalan dengan waktu awal kematian larva (Tabel 1) dimanakonsentrasi $10 \mathrm{ml}^{-l^{-1}}$ air dan $8 \mathrm{ml}^{\mathrm{l}^{-1}}$ air memberikan waktu awal kematian lebih cepat yaitu 3 jam setelah aplikasi. Hal ini dikarenakan senyawa aktif sitronela masuk ke tubuh serangga melalui mulut (oral) dan dapat menimbulkan mortalitas lebih tinggi karena kandungan senyawa yang terdapat dalam minyak serai bersifat insektisidal yang masuk melalui sistem pencernaan Spodoptera frugiperda.Menurut Soekamtoet al., (2007), bahwa senyawasenyawa yang terdapat pada minyak atsiri serai wangi diduga mengalami perubahan bentuk ke senyawa lebih beracun oleh berbagai jenis enzim yang ada pada sistem pencernaan serangga sehingga dapat meningkatkan jumlah serangga yang mati.

\subsection{Mortalitas Harian}

Hasil pengamatan mortalitas harian larva $S$. frugiperda dengan perlakuan pemberian ekstrak minyak serai wangi menunjukkan bahwa persentase kematian larva S.frugiperda mengalami fluktuasi dari hari pertama hingga hari kelima. Fluktuasi mortalitas harian larva $S$. frugiperda dapat dilihat pada Gambar 1.
Gambar 1 menunjukkan fluktuasi mortalitas harian larva S. frugiperda setelah aplikasi ekstrak minyak serai pada setiap perlakuan dari hari pertama sampai hari kelima pengamatan. Perlakuan $0 \mathrm{ml}^{-1} \mathrm{l}^{-1}$ air, sampai akhir pengamatan (120 jam) tidak mampu mematikan larva S.frugiperda. Pengamatan hari pertama merupakan puncak kematian larva $S$. frugiperda untuk semua perlakuan dengan kisaran 20\%$55 \%$. Mortalitas tertinggi hari pertama terdapat pada perlakuan konsentrasi $10 \mathrm{ml}^{-1}{ }^{-1}$ air yang menyebabkan kematian sebesar $55 \%$, diikuti perlakuan konsentrasi $8 \mathrm{ml}^{-1}$ air menyebabkan mortalitas sebesar 50\%, perlakuan konsentrasi 6 ml..$^{-1}$ air sebesar $47,5 \%$, perlakuan $4 \mathrm{ml}^{1^{-1}}$ air menyebabkan mortalitas sebesar $35 \%$ dan $2 \mathrm{ml}^{-}{ }^{-}$ ${ }^{1}$ air menyebabkan mortalitas sebesar $20 \%$.Hal ini menandakan bahwa minyak serai memiliki racun yang sangat tinggi. Prasetyoet al., (2013) menyatakan pada konsentrasi ekstrak minyak serai yang tinggi, akan mengakibatkan kematian serangga pada skala waktu 2-3 jam setelah aplikasi. Hal ini karena ekstrak minyak serai wangi mengandung senyawa aktif beracun yaitu sitronela sebesar 35,97\%. Mekanisme kerja senyawa aktif ini yaitu sebagai racun syaraf dan racun kontak. Sebagai racun kontak masuk kedalam tubuh larva melalui lubang-lubang alami pada serangga atau langsung masuk melalui mulut bersamaan dengan bahan makanan yang dimakan (Tarumingkeng, 1971) dan sebagai racun syaraf, racun sitronela masuk ke tubuh serangga melalui spirakel dan masuk ke trakea serangga, atau kelenjar sensorik dan organ lain sehingga mengakibatkan tubuh serangga kaku dan energi berkurang sehingga menimbulkan kematian (Sucipto, 2011). 


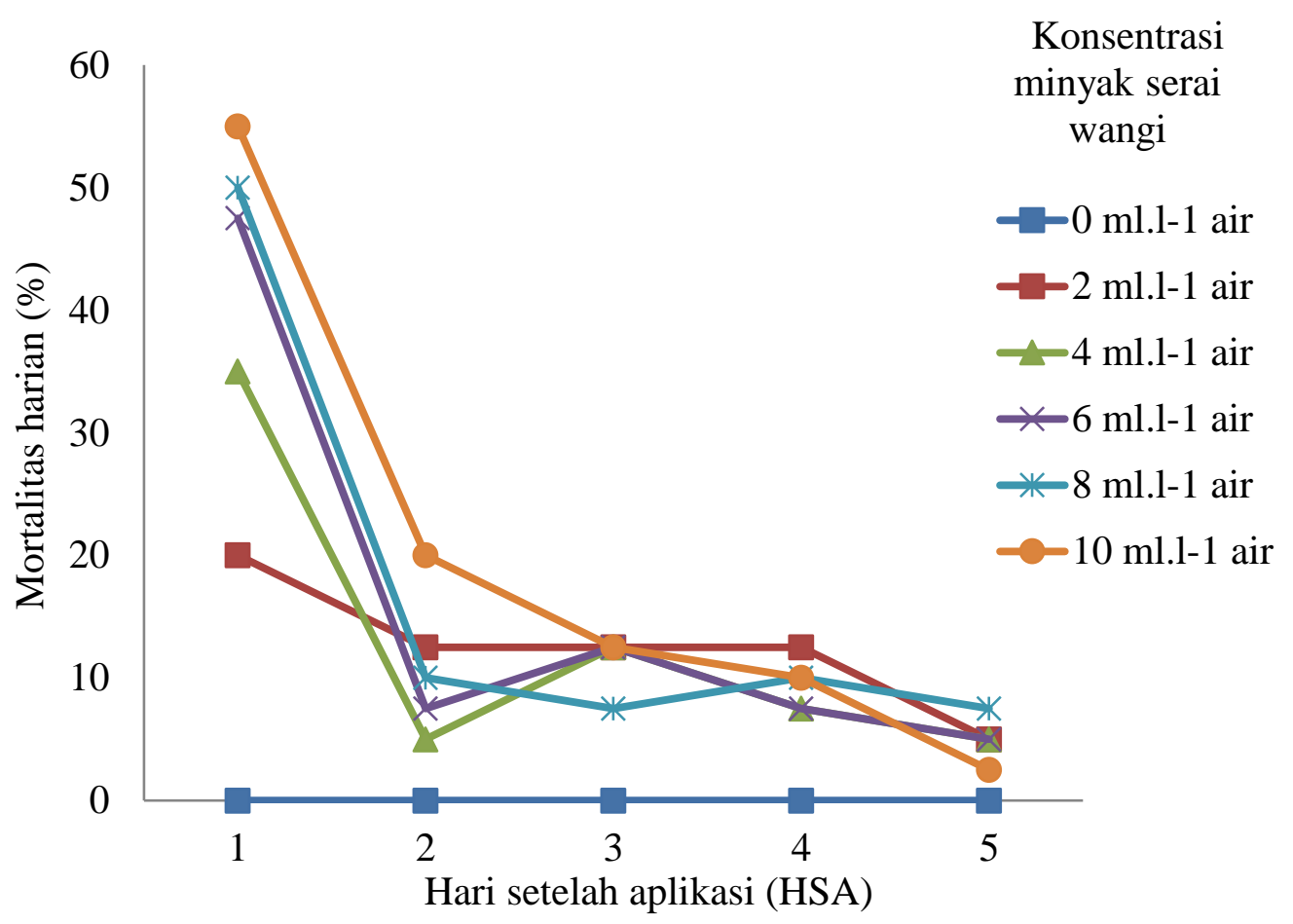

Gambar 1. Fluktuasi mortalitas harian larva S.frugiperda setelah aplikasi ekstrakminyak seraiwangi.

Pengamatan hari kedua, semua perlakuan ekstrak minyak serai wangi mengalami penurunan mortalitas harian dengan kisaran 5\%$20 \%$. Hal ini diduga karena senyawa sitronela minyak serai sudah banyak membunuh larva S.frugiperda pada hari pertama, bahkan ada yang mencapai 55\%. Penelitian Kurnia (2018) memperlihatkan persentase kematian larva $O$. rhinoceros mengalami penurunan setelah terjadinya puncak kematian. Hari ketiga pengamatan perlakuan konsentrasi $8 \mathrm{ml}^{-l^{-1}}$ air dan $10 \mathrm{ml}^{-1}$ air mengalami penurunan yaitu sebesar 2,5\% dan 7,5\%, konsentrasi $2 \mathrm{ml}^{-\mathrm{l}^{-1}}$ air masih mencapai kematian yang sama seperti hari kedua yaitu $12,5 \%$ dan konsentrasi $4 \mathrm{ml}^{-1}$ air dan $6 \mathrm{ml}^{-1}{ }^{-1}$ air mengalami kenaikan mortalitas sebesar 7,5\% dan 5\%. Pengamatan hari keempat perlakuan konsentrasi $4 \mathrm{ml} . \mathrm{l}^{-1}$ air, $6 \mathrm{ml} . \mathrm{l}^{-1}$ air dan $10 \mathrm{ml}^{\mathrm{l}^{-1}}$ air mengalami penurunan mortalitas harian yaitu 5\%, 5\% dan 2,5\%, konsentrasi 2 ml. $\mathrm{l}^{-1}$ air masih mencapai kematian yang sama seperti hari ketiga yaitu $12,5 \%$ dan konsentrasi 8 ml. $1^{-1}$ air mengalami kenaikan mortalitas sebesar $2,5 \%$. Fluktuasi mortalitas harian yang terjadi pada serangga uji diduga disebabkan oleh perbedaan konsentrasi senyawa sitronela yang masuk ke dalam tubuh larva $S$. frugiperda yang menyebabkan respon yang berbeda-beda pada serangga uji.

Pada hari kelima semua perlakuan ekstrak minyak serai wangi mengalami penurunan dengan kisaran 2,5\%-5\%. Hal ini disebabkan karena jumlah larva uji yang semakin sedikit pada setiap perlakuan ditambah dengan sifat dari minyak serai yang mudah menguap. Bota et al.,(2005) menyatakan minyak serai bersifat volatil atau mudah menguap sehingga daya racun dari minyak serai wangi menurun. Hal ini didukung oleh pernyataan Dadang dan Prijono (2008) yang menyatakan bahwa kekurangan dari pestisida nabati antara lain persistensi insektisida nabati rendah, sehingga bahan aktif yang terdapat pada insektisida nabati cepat terurai, bahkan terjadi penurunan efikasi yang cepat dari insektisida nabati sehingga memerlukan aplikasi berulang.

\subsection{Mortalitas Total (\%)}

Hasil sidik ragam menunjukkan bahwa perlakuan konsentrasi ekstrakminyak serai wangi (Cymbopogon nardus L.) memberikan pengaruh nyata terhadap mortalitas larva $S$. frugiperda (Lampiran 3). Hasil uji lanjut Duncan New Multiple RangeTest (DNMRT) 
taraf $5 \%$ parameter mortalitas total disajikan

pada Tabel 3.

Tabel 3. Rata-rata mortalitas total larva $S$. frugiperda setelah pemberian ekstrak minyak serai wangi (Cymbopogon nardus L.)(\%)

Konsentrasi ekstrakminyak serai wangi(ml. ${ }^{-1}$ air) $\quad$ Mortalitas total S.frugiperda $(\%)$

\begin{tabular}{cc}
0 & $0,00 \mathrm{~d}$ \\
2 & $62,50 \mathrm{c}$ \\
4 & $72,50 \mathrm{bc}$ \\
6 & $80,00 \mathrm{~b}$ \\
8 & $85,00 \mathrm{ab}$ \\
10 & $100,00 \mathrm{a}$ \\
\hline
\end{tabular}

Angka-angka pada kolom setiap perlakuan yang diikuti oleh huruf kecil yang tidak sama menunjukkan berbeda nyata menurut uji DNMRT pada taraf 5\%.

Tabel 3 menunjukkan bahwa perlakuan konsentrasi ekstrak minyak serai wangi memberikan pengaruh terhadap mortalitas total larva S. frugiperda dengan kisaran $62,50 \%$ $100 \%$. Konsentrasi minyak serai $2 \mathrm{ml}^{-1}{ }^{-1}$ air menyebabkan mortalitas total $S$. frugiperda sebesar 62,50\%. Peningkatan konsentrasi menjadi 4 ml. $\mathrm{l}^{-1}$ air menyebabkan mortalitas sebesar $72,50 \%$ Peningkatan konsentrasi menjadi $6 \mathrm{ml}^{-\mathrm{l}^{-1}}$ menyebabkan mortalitas cenderung lebih tinggi yaitu $80 \%$ dan sudah memperlihatkan hasil yang berbeda nyata dengan konsentrasi $2 \mathrm{ml} . \mathrm{l}^{-1}$. Hal ini diduga bahwa kandungan senyawa sitronela yang semakin tinggi akan mempercepat mortalitas larva $S$. frugiperda. Hal ini sesuai dengan pendapat Nursalet al., (1997) yang menyatakan bahwa konsentrasi ekstrak yang lebih tinggi maka pengaruh yang ditimbulkan semakin tinggi, disamping itu daya kerja suatu senyawa ditentukan oleh besarnya konsentrasi.

Konsentrasi ekstrak minyak serai $8 \mathrm{ml}^{-\mathrm{l}^{-}}$ ${ }^{1}$ air menyebabkan mortalitas total larva $S$. frugiperda sebesar $85 \%$ dan berbeda tidak nyata dengan konsentrasi $10 \mathrm{ml} . \mathrm{l}^{-1}$ dengan mortalitas total $100 \%$. Peningkatan konsentrasi dari $8 \mathrm{ml}^{-\mathrm{l}^{-1}}$ ke konsentrasi $10 \quad \mathrm{ml}^{-1}$ air cenderung menyebabkan mortalitas yang lebih tinggi. Hal ini disebabkan oleh tingginya konsentrasi minyak serai yang diberikan sehingga senyawa aktif yang bersifat toksik lebih banyak masuk ke dalam tubuh serangga dan menyebabkan larva cepat mengalami kematian. Pernyataan ini sesuai dengan Azlansah et al., (2019) yang menyatakan bahwa tinggi rendahnya angka mortalitas larva dikarenakan kandungan bahan aktif dari ekstrak. Kemampuan ekstrakminyak serai dalam mematikan larva S.frugiperda dikarenakan kandungan sitronela dalam minyak serai. Dimana senyawa aktif sitronela yang bekerja sebagai racun perut, racun kontak dan racun pernafasan sehingga mengakibatkan mortalitas larva S.frugiperda yang sangat tinggi. Senyawa ini juga mempunyai sifat sebagai racun perut, dimana senyawa aktif tersebut masuk ke tubuh serangga melalui mulut (oral) dan dapat menimbulkan mortalitas lebih tinggi karena kandungan senyawa yang terdapat dalam minyak atsiri serai wangi bersifat insektisidal yang masuk melalui sistem pencernaan S.frugiperda. Simpson dan Simpson (1990) menyatakan bahwa senyawa alelokimia yang terdapat pada makanan serangga mempengaruhi pertumbuhan dan aktivitas makan serangga dan pada akhirnya menurunkan keberhasilan hidup serangga. Aplikasi konsentrasi $6 \mathrm{ml}^{-1^{-1}}$ air minyak serai sudah efektif dalam membunuh larva S.frugiperda. Hal ini sesuai dengan pernyataan Dadang dan Prijono (2008) bahwa pestisida nabati dikatakan efektif apabila mampu mematikan serangga uji $\geq 80 \%$ dengan konsentrasi pestisida nabati tidak melebihi $10 \%$ dengan pelarut air.

Kemampuan minyak serai wangi dalam mengendalikan $S$. frugiperda lebih baik dari hasil penelitian Nurohmaningrum (2016) dimana ekstrak minyak serai pada konsentrasi $1 \%$ mampu menyebabkan mortalitas Spodoptera exigua sebesar $84 \%$, sedangkan ekstrak minyak serai yang digunakan pada penelitian ini yaitu konsentrasi $6 \mathrm{ml}^{-1^{-1}}(0,6 \%)$ air mampu menyebabkan mortalitas sebesar $80 \%$. Hal ini diduga karena jumlah sitronela dalam minyak serai yang berbeda sehingga mortalitas yang dihasilkan berbeda. 


\section{KESIMPULAN}

Uji konsentrasi ekstrak minyak serai wangi(Cymbopogon nardus L.) dalam mengendalikan ulat grayak jagung (Spodoptera frugiperda J.E Smith) di Laboratorium diperoleh kesimpulan bahwa ekstrak minyak serai wangi dengan konsentrasi $6 \mathrm{ml}^{-1}$ air sudah efektif untuk mengendalikan ulat grayak jagung karena mampu menyebabkan mortalitas total sebesar $80 \%$ dengan waktu awal kematian 6,75 jam setelah aplikasi dan $\mathrm{LT}_{50}$ pada waktu 40,50 jam setelah aplikasi.

\section{SARAN}

Berdasarkan hasil penelitian yang telah dilakukan, disarankan menggunakan konsentrasi ekstrak minyak serai wangi $6 \mathrm{ml}^{-\mathrm{l}^{-1}}$ air untuk mengendalikan ulat grayak jagung ( $S$. frugiperda) karena dapat menyebabkan mortalitas total sebesar $80 \%$ dan perlu dilakukan uji lanjut di lapangan.

\section{UCAPAN TERIMAKASIH}

Kepada PLP Laboratorium Hama Tumbuhan Fakultas PertanianUniversitas Riau, Kampus Bina Widyakm 12,5 Pekanbaru, yang telah membantu kelancaran pelaksanaan penelitian ini.

\section{DAFTAR PUSTAKA}

Aminah, S. N. 1995. Evaluasi Tiga Jenis Tumbuhan sebagai Insektisida dan Repelan terhadap Nyamuk di Laboratorium. Tesis (Tidak dipublikasikan). Institut Pertanian Bogor. Bogor.

Azlansah, A. Rusdy, dan Hasnah. 2019. Concentration Test of Jengkol Skin Ektract Against Armyworm Spodopteralitura F. at laboratory. JIM Pertanian Unsyiah. 4 (2):161-167.

Bota W, M. Martusupono dan FS, Rundonuwu. 2005. Identifikasi Senyawa Kimia Minyak Sereh Wangi Klon G3 Cymbopogon nardus L. dengan Media Tanam Tanah Gambut dan Potensinya sebagai Anti Bakteri. Jurnal Tengkawang. 9(2): 71-81.
CABI. 2019. Spodoptera frugiperda. https://www.cabi.org/isc/datasheet/29810. Diakses tanggal 6 November 2019.

Dadang dan D. Prijono. 2008. Insektisida Nabati Prinsip, Pemanfaatan dan Pengembangan. Laporan Penelitian (Tidak dipublikasikan). Departemen Proteksi Tanaman Institut Pertanian Bogor. Bogor.

Dewi, R.S. 2010. Keefektifan Ekstrak Tiga Jenis Tumbuhan terhadap Paracoccus marginatus dan Tetranychus sp. Pada Tanaman Jarak Pagar (Jatrophacurcas L). Tesis (Tidak di publikasikan). Institut Pertanian Bogor. Bogor.

Direktorat Jenderal Perkebunan.2019. Waspada Spodoptera frugiperda J.E Smith. KementerianPertanian.http://perlindungan .ditjenbun.pertanian.go.id/web/page/title/3 19980/waspada-spodoptera-

frugiperda?post_type=informasi. Diakses pada tanggal 20 April 2020.

Dono, D., D. Prijono, S. Manuwato, D. Buchori, Dadang dan Hasin. Pengaruh rokaglamida dan parasitoid Eriborusargenteopilosus kadar dan profil protein hemolimfa larva Crocidolomiapavona melanisasi kutikula. Jurnal Agrikultura. 17(3): 185194.

Hasyim, A. W. Setiawati, R. Murtiningsih dan E. Sofiari. 2010. Efikasi dan Persistensi Minyak Serai sebagai Biopestisida terhadap Helicoverpa armigera Hubn. (Lepidoptera: Noctuidae). Jurnal Hortikultura. 20(4): 377- 386.

Juliati,M. Mardiansyah dan T. Arlita. 2016. Uji Beberapa Konsentrasi Ekstrak Daun Bintaro (Cerberamaghas L.) sebagai Pestisida Nabati untuk Mengendalikan Ulat Jengkal (Plusiasp) pada Trembesi (Samaneasaman Jacq). JOM Faperta UR. 3(1):3-5.

Kementerian Pertanian. 2020. https://aplikasi2.pertanian.go.id/bdsp/id/k omoditas. Diakses tanggal 29 Februari 2020.

Kurnia, H. 2018. Daya Bunuh Ekstrak Tepung Daun Sirih Hutan (Piper aduncum L) terhadap Larva Kumbang Tanduk (Oryctes rhinoceros L.) Hama pada Tanaman Kelapa Sawit. Skripsi (Tidak 
dipublikasikan). Universitas Riau. Pekanbaru.

Maharani, Y. Vira, K. D. Lindung, T. P. Lilian, R. Yusup dan Danar. 2019. Cases of Fall Armyworm Spodoptera frugiperda J. E. Smith (Lepidoptera: Noctuidae) attack on maize in Bandung, Garut and Sumedang District, West Java. Jurnal Cropsaver. 2(1): 38-46.

Mulyana. 2002. Ekstraksi Senyawa Aktif Alkaloid, Kuinon dan Saponin dari Tumbuhan Kecubung sebagai Larvasida dan Insektisida terhadap Nyamuk Aedes aegepti. Skripsi (Tidak dipublikasikan). Institut Pertanian Bogor. Bogor.

Muryati, Trisyono, Witjaksono dan Wahyono. 2012. Effects of Citronella Grass Extract on Oviposition Behavior of Carambola Fruit Fly (Bactrocera carambolae) in Mango. ARPN Journal of Agricultural and Biological Science. 7(9): 279-679.

Mutchler, E. 1991. Dinamika Obat :Buku Ajar Farmakologi dan Toksikologi. Edisi 5. Diterjemahkan oleh Widianto, M. dan A.S. Kanti. ITB. Bandung .

Nurohmaningrum, L. 2016. Efektivitas Formulasi Minyak Atsiri Serai Wangi sebagai Biolarvasida Larva Spodoptera exigua pada Tanaman Bawang Merah. Skripsi (Tidak dipublikasikan). UN PGRI Kediri.

Nursal, E., P. S. Sudharto dan R. Desmier. 1997. Pengaruh Konsentrasi Ekstrak Bahan Pestisida Nabati terhadap Hama. Balai Penelitian Tanaman Obat. Bogor.
Prasetyo, H. D, I.W. Susila, K. Sumiartha. 2013. Efikasi Minyak Atsiri Sereh Dapur (Cymbopogon citratus L.) terhadap Hama Ulat Daun Kubis (Plutella xylostella L.) di Laboratorium. E-Journal Agroteknologi Tropika. Vol. 2(2) : 99-107.

Sastrohamidjojo. 2004. Kimia Minyak Atsiri. Gajah Mada University Press. Yogyakarta.

Sasmita, L., L.Z. Lusi dan Meriko. 2014. Uji Efektivitas Minyak Serai Wangi (Andropogonnardus L.) terhadap Kutu Daun (Aphis gossypii G.) (Homoptera: Aphididae). Skripsi (Tidak dipublikasikan). Sekolah Tinggi Keguruan dan Ilmu Pendidikan (STKIP) PGRI Sumatera Barat.

Soekamto, Zainudin, O., Solichah dan Poerwanto. 2007. Perlakuan Benih Padi yang Disimpan dengan Pestisi dan Abatiserai Wangi terhadap Hama Bubuk Padi (SitophilusoryzaeL.). Jurnal Median. 11 (2): 18-22.

Sucipto, D. C. 2011. Vektor Penyakit Tropis. Gosyen. Yogyakarta.

Tarumingkeng, R. C. 1992. Insektisida: Sifat, Mekanisme Kerjadan Dampak Penggunaannya. Penerbit Ukrida. Jakarta.

Untung , K. 2006. Pengantar Pengendalian Hama Terpadu.Gajah Mada University press. Yogyakarta. 
